\title{
CARA PENJUAL DAN PEMBELI BERTINDAK TUTUR DIREKTIF DALAM PERCAKAPAN DI FORUM JUAL BELI SITUS PASAR ONLINE KASKUS
}

\author{
Anita Risma Pratiwi \\ Anita-risma@yahoo.co.id \\ Program Studi Magister Ilmu Linguistik, Fakultas Ilmu Budaya. Universitas \\ Airlangga
}

\begin{abstract}
During communicating within the field of trading, speakers often apply illocutionary speech acts, namely directive speech acts. It is expressed by the speakers to their speech partner so they are willing to do what the speakers want. However, there very few studies that examined directive speech acts on buying and selling activities on an Indonesian online market site, especially Kaskus. This study aimed to understand the ways in which directive speech acts were carried out by sellers and buyers in conversations on the Kaskus Trading Forum. Both the sellers and buyers used directive speech acts by using imperative sentences and fenced performative sentences. However, the directive speech acts carried out by sellers were different from their buyers in terms of variety of the directive sentences. In addition, only buyers who use the directive speech acts in interrogative sentence.

Keywords: kaskus, buyer, seller, speech act, directive sentences
\end{abstract}

\section{Abstrak}

Dalam berkomunikasi di bidang perdagangan, seringnya penutur mengaplikasikan tindak tutur ilokusi, yaitu tindak tutur direktif yang diutarakan oleh penutur kepada mitra tuturnya agar mau melakukan apa yang dikehendaki si penutur. Namun, belum ada penelitian sebelumnya yang meneliti tindak tutur direktif pada kegiatan jual beli di suatu situs pasar online Indonesia, khususnya Kaskus. Penelitian ini bertujuan untuk memahami cara-cara tindak tutur direktifyang dilakukan oleh penjual dan pembeli dalam percakapan di Forum Jual Beli Kaskus. Baik penjual maupun pembeli bertindak tutur direktif dengan cara menggunakan kalimat imperatif dan kalimat performatif berpagar. Akan tetapi, yang membedakan adalah dari tindak tutur direktif yang dilakukan oleh penjual terhadap pembeli mereka menggunakan ragam kalimat direktif yang berbeda. Selain itu hanya pembeli yang menggunakan kalimat direktif pertanyaan.

Kata Kunci: kaskus, pembeli, penjual, tindak tutur, kalimat direktif

\section{PENDAHULUAN}

Manusia diciptakan Tuhan sebagai makhluk sosial. Setiap individu membutuhkan kontak sosial dengan individu yang lainnya. Cara mereka agar dapat berinteraksi sosial yaitu melalui komunikasi. Dalam kehidupan sehari-hari manusia menggunakan bahasa untuk berkomunikasi. Bahasa merupakan alat komunikasi yang paling utama sebab dengan bahasa penutur dapat menyampaikan dan mengekspresikan ide, pikiran, dan gagasan yang dimilikinya kepada mitra tutur. Dalam menggunakan bahasa untuk komunikasi, harus disesuaikan dengan kondisi dan situasi pada saat itu agar maksud dan tujuan yang disampaikan oleh penutur kepada mitra tuturnya dapat tercapai. Singkatnya, bahasa yang digunakan oleh penutur disesuaikan dengan konteksnya.

Dalam berkomunikasi, penutur tentunya menggunakan gaya yang berbeda 
disesuaikan dengan tujuannya. Ilmu yang mengkaji tentang bahasa dalam komunikasi dan makna kontekstualnya masuk dalam ranah kajian pragmatik. Seperti yang disampaikan oleh Levinson (1983) yang dikutip oleh Rahardi (2009) bahwa pragmatik sebagai studi bahasa yang mempelajari hubungan bahasa dengan konteksnya. Pendapat tersebut didukung pula oleh Mey (1983), ia mengatakan bahwa pragmatik ialah sebuah studi tentang kondisi bahasa yang digunakan manusia dan ditentukan oleh konteks masyarakatnya (Rahardi, 2009:21). Sehingga pragmatik sangat erat kaitannya dengan konteks, sedangkan hal itu berlawanan dengan studi tata bahasa atau gramatika yang mana terlepas dari konteksnya.

Kajian tentang tuturan ini tidak hanya terbatas pada tuturan lisan, melainkan juga pada komunikasi tertulis. Dengan maraknya media sosial, pola komunikasi manusia pun perlahan mengalami peralihan dari komunikasi tutur ke komunikasi tertulis. Uniknya, fitur-fitur pada aplikasi media sosial memungkinkan terjadinya komunikasi dua arah. Sebut saja whatsapp, instagram, telegram, dan facebook messenger yang merupakan sedikit dari platform social media yang memfasilitasi komunikasi tertulis dua arah. Pola komunikasi ini dapat dilihat melalui teori tindak tutur.

Yule (1996:3) berpendapat "pragmatik adalah studi tentang maksud penutur". Seorang penutur agar maksud dan tujuan tuturannya dapat tersampaikan kepada mitra tuturnya, maka ia tidak hanya menghasilkan tuturan berupa kata-kata dan tata bahasanya saja akan tetapi secara bersamaan juga harus diwujudkan melalui tindakan-tindakan yang disebut dengan tindak tutur (Yule, 1996:81-82). Rahardi (2009:17) memaparkan, Austin (1962) dan Searle (1969) dalam buku Speech Acts: An Essay in The Philosophy of Language mengklasifikasikan tiga macam tindak tutur berdasarkan dari penggunaan bahasanya, antara lain tindak lokusi ialah tindak tutur melalui kata, frasa, kalimat, dan maknanya sesuai dengan kata, frasa, dan kalimat tersebut. Kedua, tindak ilokusi ialah tindak tutur melakukan sesuatu dengan maksud dan fungsi tertentu dalam kegiatan bertutur yang sesungguhnya. Ketiga, tindak tutur perlokusi ialah tindak tutur untuk mempengaruhi mitra tutur agar melakukan suatu tindakan sebagai efek dari tuturan penutur.

Dalam hal ini tindak tutur ilokusi merupakan titik pusat yang paling utama dari penelitian. Adapun Searle (1983) seperti yang dikutip oleh Rahardi (2009), membagi lima jenis tindak tutur ilokusi berdasarkan dari fungsi bahasanya, yaitu sebagai berikut; (1) Asertif (representative) adalah mengikat penutur pada kebenaran atas apa yang diucapkannya, bentuk tuturannya seperti menyarankan, mengeluh, mengklaim. (2) Direktif adalah mempengaruhi mitra tutur agar melakukan tindakan-tindakan yang dikehendaki penutur, seperti memesan, memerintah, memohon, menasehati, merekomendasi. (3) Ekspresif adalah menunjukkan sikap psikologis penutur terhadap keadaan tertentu, seperti berterima kasih, memberi selamat, meminta maaf, memuji, menyalahkan, berbela sungkawa. (4) Komisif adalah menyatakan janji atau penawaran, seperti berjanji, bersumpah, menawarkan sesuatu. (5) Deklarasi adalah 
menghubungkan isi tuturan dengan kenyataan seperti memecat, membabtis, memberi nama, mengangkat, menghukum.

Dari sejumlah penelitian yang membahas tentang komunikasi tertulis di media sosial, belum banyak penelitian sebelumnya yang meneliti tindak tutur direktif pada kegiatan jual beli di suatu situs pasar online Indonesia. Oleh karena itu, peneliti menarik untuk meneliti salah satu tindak ilokusi yakni tindak tutur direktif pada percakapan antara penjual dan pembeli di dalam Forum Jual Beli situs pasar online Kaskus. Kaskus The Largest Indonesian Community berasal dari singkatan "kasak-kusuk" dan didirikan 15 tahun yang lalu, tepatnya 16 November 1999 oleh tiga pelajar Indonesia di Seattle, Amerika Serikat (http://id.wikipedia.org/wiki/Kaskus).

Awalnya mereka membuat Kaskus sebagai tugas kuliah dan bertujuan untuk memberikan informasi mengenai berita-berita di Indonesia yang diterjemahkan (http:// support.kaskus.co.id/about/sejarah_kaskus.html). Kaskus merupakan situs forum komunitas maya terbesar dan menduduki peringkat pertama di Indonesia. Anggota komunitas Kaskus, yang biasa disebut dengan Kaskuser, tersebar dari seluruh pelosok Indonesia. Dalam situs Kaskus terdapat berbagai macam fitur yang tersedia, salah satunya yaitu Forum Jual Beli (FJB). Forum ini merupakan tempat berlangsungnya kegiatan jual dan/beli barang maupun jasa. Para penjual dan pembeli dalam FJB saling berinteraksi dan berkomunikasi untuk menyampaikan maksud dan tujuan mereka.

Fenomena jual dan/beli barang dan jasa di FJB Kaskus menarik perhatian peneliti untuk meneliti tindak tutur direktif pada percakapan mereka. Sehingga nantinya akan terlihat bagaimana cara tindak tutur penjual dalam menjajakan dagangannya kepada pembeli dan bagaimana cara tindak tutur pembeli dalam membeli barang atau jasa dari penjual. Pada penelitian kali ini peneliti fokusnya pada ranah transaksional bisnis dalam Forum Jual Beli situs pasar online Kaskus. Menurut Rahardi (2009:39) terdapat delapan ranah untuk melihat bentuk-bentuk kebahasaan yang mengandung makna sosiopragmatik imperatif, yakni ranah pendidikan, ranah perkantoran, ranah kemasyarakatan, ranah pemerintahan, ranah transaksional bisnis, ranah keagamaan, ranah kekeluargaan, dan ranah media.

Dalam penelitian kali ini difokuskan hanya pada salah satu tindak tutur ilokusi, yaitu tindak tutur direktif yang mana juga merupakan salah satu kajian dalam studi sosiopragmatik yang seringkali diteliti. Tindak tutur ini merupakan suatu tindak tutur yang diutarakan oleh penutur kepada mitra tuturnya agar mau melakukan apa yang dikehendaki si penutur. Singkatnya, berdasarkan dari apa yang telah dipaparkan sebelumnya, masalah yang dikaji dalam penelitian ini yakni: 1) Bagaimanakah cara tindak tutur direktif yang dilakukan penjual terhadap pembeli dalam percakapan di Forum Jual Beli Kaskus? 2) Bagaimanakah cara tindak tutur direktif yang dilakukan pembeli terhadap penjual dalam percakapan di Forum Jual Beli Kaskus?

Penelitian ini diharapkan mampu memberikan kontribusi teoretis dan praktis. Secara teoritis, penelitian ini diharapkan dapat memperkaya khasanah tentang penelitian 
linguistik kajian pragmatik khususnya mengenai kajian tindak tutur direktif dan dapat menjadi referensi bagi penelitian selanjutnya yang terkait. Smentara itu, manfaat praktis dari penelitian ini diharapkan dapat memberikan pengetahuan mengenai cara penjual dan pembeli menerapkan tindak tutur direktif dalam percakapan di Forum Jual Beli Kaskus.

\section{LANDASAN TEORI}

Kajian pragmatik menurut Leech (1993) ialah studi tentang maksud dalam hubungannya dengansituasi-situasi tuturan (speech interaction) (http://www.scribd. com/doc/48254615/sejarah-singkat-pragmatik). Yule (1996) berpendapat bahwa pragmatik mengkaji makna tuturan si penutur yang mana terpisah dari makna dari kata dan kalimat itu sendiri, sehingga pragmatik itu sangat berkaitan dengan makna kontekstual. Tindakan-tindakan yang ditampilkan melalui tuturan disebut dengan tindak tutur (Yule, 1996:82). Searle (1983) membagi tiga jenis tindak tutur, yakni tindak lokusi, ilokusi, dan perlokusi. Dalam penelitian ini yang menjadi fokus dalam pembahasan yaitu tindak ilokusi berdasarkan dari fungsi direktif.

Rahardi (2009) menguraikan sembilan macam cara untuk menyatakan maksud direktif berdasarkan dari teori yang dikemukakan oleh Kulka (1987), antara lain (1) kalimat imperatif adalah kalimat yang mengandung perintah dan berfungsi untuk meminta atau melarang seseorang untuk melakukan sesuatu. (2) Kalimat performatif eksplisit adalah kalimat yang berisi perlakuan, tuturan yang diucapkan penutur bersifat terus terang atau gamblang. (3) Kalimat performatif berpagar merupakan kalimat tak langsung dan memiliki fungsi untuk memperhalus tuturan agar terdengar lebih sopan. (4) Pernyataan keharusan merupakan kalimat langsung untuk menyuruh seseorang melakukan tindakan yang dikehendaki penutur. (5) Pernyataan keinginan menyatakan keingininan si penutur yang disampaikan kepada mitra tutur secara tak langsung. (6) Rumusan saran merupakan tuturan dari si penutur berupa kalimat saran untuk meminta mitra tutur melakukan sesuatu sesuai dengan yang dikehendakinya (7) Pertanyaan adalah tuturan dari si penutur berupa kalimat tanya untuk meminta mitra tutur melakukan sesuatu sesuai dengan yang dikehendakinya. (8) Isyarat kuat adalah tuturan yang diucapkan penutur dengan jelas dan terus terang untuk mengutarakan keinginannya kepada mitra tutur. (9) Isyarat halus adalah tuturan yang diucapkan penutur dengan samar untuk mengutarakan keinginannya kepada mitra tutur.Dalam menyampaikan maksud direktif, Blum Kulka (1987) mengkategorikan sembilan macam cara yang dapat dilakukan oleh penutur (Rahardi, 2009:18). (1) Kalimat imperatif (“Tutup pintu itu!”). (2) Kalimat performatif eksplisit (“Saya minta Saudara menutup pintu itu!"). (3) Kalimat performatif berpagar ("Sebenarnya saya mau minta Saudara menutup pintu itu”). (4) Pernyataan keharusan ("Saudara harus menutup pintu itu!"). (5) Pernyataan keinginan (“Saya ingin pintu itu ditutup”). (6) Rumusan saran (“Bagaimana kalau pintu itu ditutup?”). (7) Pertanyaan (“Saudara dapat menutup pintu 
itu?”). (8) Isyarat kuat (“Dengan pintu seperti itu, saya kedinginan"). (9) Isyarat halus ("Saya kedinginan").

Penelitian terdahulu yang terkait dengan studi mengenai tindak tutur direktif telah banyak dilakukan, khususnya di Indonesia. Seperti penelitian yang dilakukan oleh Etikasari (2012) dalam artikel penelitiannya mengkaji tentang bentuk dan fungsi tindak tutur direktif dalam wacana kelas. Hasil penelitiannya menunjukkan bahwa terdapat delapan bentuk tindak tutur direktif dalam wacana kelas, yakni suruhan, perintah, permintaan, ajakan, desakan, larangan, menyarankan, dan bujukan. Sedangkan fungsi tindak tutur direktif dalam wacana kelas meliputi suruhan, perintah, permintaan, ajakan, desakan, larangan, menyarankan, dan bujukan. Penelitian selanjutnya yang dilakukan Elmita et.al. (2013) meneliti tentang bentuk dan strategi tindak tutur direktif guru dalam proses belajar mengajar di TK Nusa Indah Banuaran Padang. Hasil dari penelitian tersebut menunjukkan bahwa bentuk-bentuk tindak tutur direktif guru dalam proses belajar mengajar di TK Nusa Indah Banuaran Kecamatan Lubuk Begalung Padang ada lima bentuk, yaitu tindak tutur direktif menyuruh, tindak tutur direktif memohon, tindak tutur direktif menyarankan, tindak tutur direktif menasehati dan tindak tutur direktif menantang. Sedangkan strategi bertutur yang digunakan guru dalam proses belajar mengajar di TK Nusa Indah Banuaran Kecamatan Lubuk Begalung Padang ada dua, yaitu strategi bertutur terus terang tanpa basa-basi dan strategi bertutur terus terang dengan basa-basi kesantunan positif.

\section{METODE PENELITIAN}

Pendekatan yang digunakan peneliti dalam penelitian ini ialah kualitatif deksriptif, karena memberikan deskripsi nyata mengenai cara-cara tindak tutur yang dilakukan oleh penjual dan pembeli dalam percakapan di Forum Jual Beli Kaskus. Maka, data dilaporkan dalam bentuk kata-kata (utamanya pada kata-kata partisipan) daripada dalam bentuk angka (Fraenkel \& Wallen, dikutip dari Creswell. 1994). Metode yang digunakan oleh peneliti yaitu random sampling, dengan hanya mengambil perwakilannya saja dari suatu komunitas secara acak. Sedangkan data penelitian diambil dengan cara menyimak percakapan di Forum Jual Beli Kaskus tanpa berpartisipasi atau terlibat di dalamnya. Teknik ini biasa disebut dengan "teknik simak bebas libat cakap" atau "SBLC" (Sudaryanto, 1993). Dalam teknik ini, peneliti tidak terlibat sama sekali di dalam dialog atau percakapan. Peneliti juga tidak bertindak sebagai pembicara, namun hanya mendengarkan/melihat dan memperhatikan percakapan. Selanjutnya, peneliti melakukan teknik pencatatan atas percakapan para partisipan.

Partisipan dalam penelitian ini pada umumnya usia remaja sampai dengan dewasa, berkisar antara 15 - 40 tahun, berjenis kelamin laki-laki dan perempuan, berasal dari seluruh daerah di Indonesia, rata-rata memakai Bahasa Indonesia tidak baku, dan mayoritas dari kelas sosial menengah sampai dengan ke atas. 
Dalam mengumpulkan data, peneliti melakukan empat tahapan. Pertama, peneliti memilih seluruh jenis kategori barang dan jasa yang dijual di Forum Jual Beli Kaskus. Kedua, mengamati percakapan para penjual dan pembeli dalam melakukan transaksi di forum tersebut. Ketiga, melalukan pencatatan dan mengkategorikan cara mereka bertindak tutur direktif sesuai dengan teori yang dikemukakan oleh Blum Kulka (1987). Keempat, setelah data berhasil dikumpulkan secara lengkap, langkah terakhir yaitu menganalisis percakapan.

\section{HASIL DAN PEMBAHASAN}

Pada analisis data, peneliti mengidentifikasi; (1) cara-cara tindak tutur direktif yang dilakukan penjual terhadap pembeli dan (2) cara-cara tindak tutur direktif yang dilakukan pembeli terhadap penjual dalam percakapan di Forum Jual Beli Kaskus. Berikut adalah penyajian analisis data berupa tabel.

Tabel 2.1. Cara Tindak Tutur Direktif yang Dilakukan Penjual terhadap Pembeli

\begin{tabular}{|c|c|}
\hline $\begin{array}{l}\text { Cara Tindak Tutur } \\
\text { Direktif }\end{array}$ & Penjual \\
\hline Kalimat Imperatif & $\begin{array}{l}\text { 1. "Dapatkan produk organizer menarik Lainnya" (imperatif } \\
\text { bujukan). } \\
\text { 2. "Jangan lupa timpuk ane pake cendol (imperatif permintaan)". } \\
\text { 3. "Ganti dengan yang ini sista! Dijamin hijab sista mudah dirapikan } \\
\text { kembali" (imperatif bujukan). } \\
\text { 4. "Silahkan kontak kami untuk lebih jelasnya. Thanks bro \& sis “ } \\
\text { (imperatif persilaan). } \\
\text { 5. "Hahaha bisa aja nih bro...monggo diborong Lingerie’nya, yang } \\
\text { banyak ya" (imperatif persilaan). } \\
\text { 6. "Kosong gan, akan dikabari kalo sudah ready" (imperatif } \\
\text { pemberitahuan). } \\
\text { 7. "Para aganwati yang buka ini thread tolong disundul dunk" } \\
\text { (imperatif permintaan). }\end{array}$ \\
\hline $\begin{array}{l}\text { Kalimat Performatif } \\
\text { Eksplisit }\end{array}$ & - \\
\hline $\begin{array}{l}\text { Kalimat Performatif } \\
\text { Berpagar }\end{array}$ & $\begin{array}{l}\text { 1. Kalo mau informasi lebih jelas bisa hubungi kita langsung ke hp } \\
\text { juga bisa }\end{array}$ \\
\hline Pernyataan Keharusan & 1. "Ini harus dibersihkan dulu supaya tidak ada debu dan rapi" \\
\hline Pernyataan Keinginan & - \\
\hline Rumusan Saran & - \\
\hline Pertanyaan & - \\
\hline Isyarat Kuat & - \\
\hline Isyarat Halus & - \\
\hline
\end{tabular}

Tabel 2.1. menunjukkan bahwa dari sembilan pola tindak tutur direktif, pedagang 
Kaskus yang menjadi sampel di penelitian ini hanya menggunakan tiga pola kalimat yaitu kalimat imperatif, performatif berpagar, dan keharusan.

Sebagian besar pola kalimat yang digunakan adalah kalimat imperatif. Dalam berkomunikasi, terdapat dua kalimat imperatif bujukan yang muncul. Sementara itu, terdapat juga dua kalimat imperatif permintaan yang tampak pada kalimat pedagang. Dua kalimat imperatif persilaan juga tampak pada kalimat pedagang. Yang terakhir adalah imperatif pemberitahuan.

Tabel 2.2. Cara Tindak Tutur Direktif yang Dilakukan Pembeli terhadap Penjual

\begin{tabular}{|c|c|}
\hline $\begin{array}{l}\text { Cara Tindak Tutur } \\
\text { Direktif }\end{array}$ & Pembeli \\
\hline Kalimat Imperatif & $\begin{array}{l}\text { 1. "Gan.. kalo Notepal U2 silver ke semarang nettnya berapa? PM } \\
\text { (Personal Message via BBM) yak!" (imperatif permintaan) } \\
\text { 2. "Nah, sesuai janji gw tadi , coba cek kulkas ente gan, ada segelas } \\
\text { cendol seger menanti...hehe.." (imperatif permintaan). } \\
\text { 3. "Makassar - Surabaya, cariinn yang palling murah ya gan! “" } \\
\text { (imperatif permintaan). } \\
\text { 4. "Boz, alamat lengkapnya dunkz, biar bisa lansung meluncur" } \\
\text { (imperatif permintaan) }\end{array}$ \\
\hline $\begin{array}{l}\text { Kalimat Performatif } \\
\text { Eksplisit }\end{array}$ & - \\
\hline $\begin{array}{l}\text { Kalimat Performatif } \\
\text { Berpagar }\end{array}$ & $\begin{array}{l}\text { 1. "Kalo berkenan bagi cendolnya ya gan". } \\
\text { 2. "Kalo ada diskon-diskon lagi mau dong, mau pesen lagi nih". } \\
\text { 3. "Sist besok mudah2an kalo gak ada halangan mau mampir ke toko } \\
\text { buat liat-liat rantai jam, mungkin ada yang jodoh ama jam swiss army } \\
\text { ane". } \\
\text { 4. Kalo ngasih diskonan jangan sungkan2. }\end{array}$ \\
\hline Pernyataan Keharusan & - \\
\hline Pernyataan Keinginan & - \\
\hline Rumusan Saran & - \\
\hline Pertanyaan & $\begin{array}{l}\text { 1. "Bisa request bentuk gitu kan gan?" } \\
\text { 2. "Minggu depan saya rencana balik ke Indonesia, jadi pas datang } \\
\text { tinggal pasang aja bisa ndak bro?" } \\
\text { 3. "Ndak ada YM ya bro jadi bisa ngobrol langsung?" } \\
\text { 4. "Bisa dikirim cendolnya ndak gan?" }\end{array}$ \\
\hline Isyarat Kuat & - \\
\hline Isyarat Halus & - \\
\hline
\end{tabular}

Tabel 2.2. menunjukkan bahwa, pembeli menggunakan tiga pola kalimat direktif, yakni kalimat imperatif, kalimat performatif berpagar, dan kalimat pertanyaan. Dua jenis kalimat imperatif pertama juga muncul di kalimat pedagang, namun kalimat pertanyaan hanya muncul di pembeli. Kalimat imperatif yang muncul di komunikasi pembeli hanya merupakan kalimat imperatif permintaan.

Berdasarkan dari data yang diperoleh, hasil analisis menunjukkan bahwa penjual bertindak tutur direktif terhadap pembeli dalam percakapan di Forum Jual Beli Kaskus yakni melalui cara kalimat imperatif, kalimat performatif berpagar, dan keharusan. Hampir sebagian besar penjual melakukan tindak tutur dengan kalimat 
imperatif dengan beberapa macam maknanya, antara lain bermakna permintaan, bujukan, persilaan, dan pemberitahuan. Hal itu disebabkan karena mereka berusaha untuk menyuruh para pembeli untuk membeli barang atau jasanya, baik dengan tuturan langsung maupun tidak langsung. Penjual juga menggunakan kalimat performatif berpagar dengan tujuan menyuruh pembeli untuk bertanya lebih lanjut dan detail mengenai produknya dengan cara memperhalus tuturan direktif mereka. Selanjutnya, penjual melakukan pernyataan keharusan kepada pembeli sebab ia memiliki wewenang lebih terhadap produknya tentang peraturan yang berlaku dalam kegiatan transaksi.

Sedangkan hasil analisis cara pembeli bertindak tutur direktif terhadap penjual dalam percakapan di Forum Jual Beli Kaskus yakni melalui kalimat imperatif, kalimat performatif berpagar, dan pertanyaan. Sebagian besar pembeli melakukan tindak tutur dengan kalimat imperatif yang bermakna permintaan. Seperti yang dipaparkan oleh Yule (1996:93) bahwasanya "tindak tutur direktif ialah tindak tutur yang dipakai oleh penutur untuk menyuruh orang lain melakukan sesuatu”. Rata-rata para pembeli bertindak tutur direktif melalui kalimat imperatif yaitu karena mereka meminta penjual untuk memberikan servis yang baik terhadap mereka, termasuk memberikan diskon atau harga yang murah. Data yang terlihat di tabel, menunjukkan bahwa pembeli lebih banyak bertindak tutur direktif melalui kalimat performatif berpagar daripada penjual. Pada dasarnya mereka ingin diberikan harga murah atau diskonan dari penjual namun dikemas dengan tuturan yang lebih halus dan sopan dengan harapan keinginan mereka dapat tercapai. Selanjutnya, pembeli melakukan tindak tutur direktif melalui pertanyaan dengan tujuan menyuruh penjual agar berkenan melakukan keinginan dan kehendak mereka melalui tuturan yang tidak langsung sehingga suruhan mereka terdengar lebih halus.

Perbedaan yang terdapat pada tindak tutur pedagang dan pembeli muncul karena ada perbedaan tujuan. Pedagang berkeinginan agar pembeli membeli dagangan mereka, sementara pembeli ingin mendapat harga yang lebih murah dan informasi yang lebih jelas mengenai produk yang ingin mereka beli. Oleh karenanya kedua belah pihak menggunakan strategi yang berbeda untuk mengambil hati lawan komunikasinya supaya keinginan mereka terpenuhi. Perbedaan ragam kalimat imperatif yang digunakan kedua belah pihak merupakan salah satu implikasi perbedaan maksud mereka.

Di kalimat pedagang, terdapat setidaknya empat jenis kalimat imperatif, sementara pada kalimat pembeli, hanya terdapat satu jenis kalimat imperatif. Hal ini mengindikasikan bahwa cara yang dilakukan pedagang pada sampel penelitian ini lebih beragam daripada pembeli untuk mencapai tujuan mereka. Kalimat imperatif bujukan, misalnya, digunakan untuk merayu calon pembeli untuk tetap membeli produknya bahkan ketika calon pembeli merasa produk tersebut kurang sesuai dengan yang dia cari. Kalimat imperatif bujukan ini muncul saat pedagang menawarkan produk lain di lapaknya. Kalimat imperatif bujukan ini tidak muncul di pembeli yang menjadi sampel penelitian ini. 
Kalimat imperatif permintaan muncul di kedua belah pihak meskipun disampaikan dengan tujuan yang berbeda. Pihak pedagang menggunakan pola kalimat ini hanya untuk meminta pembeli memberi review bagus atau mempromosikan lapaknya. Dirasa tidak etis jika pedagang meminta pembeli untuk membeli dengan permintaan lugas. Sehingga kalimat imperatif permintaan ini hanya digunakan untuk media promosi. Sementara itu, kalimat imperatif permintaan digunakan pembeli untuk meminta informasi lebih lanjut terkait kegiatan jual beli mereka dan untuk meminta diskon atau harga yang lebih murah. Frekuensi penggunaan kalimat imperatif ini mengindikasikan bahwa yang diminta pembeli bukan merupakan hal yang harus diutarakan dengan cara yang diperhalus karena yang diminta hanyalah informasi tambahan. Selain itu, dinilai wajar di kegiatan jual beli jika pembelilah yang meminta harga yang lebih murah. Pedagang yang meminta pembeli untuk membeli dagangannya secara lugas dinilai terlalu agresif.

Kalimat imperatif lain yang muncul adalah kalimat imperatif persilaan. Kalimat ini hanya muncul di kalimat pedagang. Kalimat dengan pola ini digunakan pedagang untuk memberikan ruang seluas-luasnya kepada pembeli. Mempersilahkan untuk bertanya lebih lanjut seperti yang tampak pada kalimat sampel di Tabel 2.1 menunjukkan kesediaan pedagang untuk menjawab berbagai pertanyaan pembeli seputar produk tanpa ada perintah untuk membeli. Hal dapat menjadi usaha pedagang untuk memberi ruang kepada pembeli dalam mengambil keputusan.

Dua pola kalimat yang muncul dalam frekuensi sedikit adalah kalimat keharusan yang muncul di sampel pedagang dan kalimat pertanyaan yang hanya muncul di sampel pembeli. Kalimat keharusan ini tidak digunakan sampel pedagang untuk membuat calon pembeli membeli produknya. Alih-alih hanya digunakan untuk membuat pembeli merawat produk yang telah dibeli sesuai dengan keinginan sampel pedagang. Hal ini megindikasikan bahwa pedagang menghindari cara-cara agresif untuk membujuk calon pembelinya untuk membeli produknya. Kemudian, kalimat pertanyaan yang hanya muncul di sampel pembeli berisi keinginan pembeli agar pedagang melakukan suatu hal dalam proses transaksinya supaya kegiatan jual beli dapat berlangsung. Keinginan sampel pembeli ini disampaikan melalui kalimat pertanyaan untuk memperhalus proses komunikasi mereka. Selain itu pola ini dapat juga mengindikasikan keinginan sampel pembeli untuk mendapatkan konfirmasi tertentu dari pedagang.

Kalimat imperatif lebih banyak muncul daripada jenis kalimat lain bisa disebabkan keterbatasan komunikasi tertulis dalam menyampaikan maksud penuturnya. Kalimat imperatif membuat maksud dari penutur dapat tersampaikan sejelas yang dimungkinkan dalam kalimat-kalimat singkat. Meskipun komunikasi berjalan dua arah, tetapi tidak terjadi dalam waktu yang bersamaan. Seringkali kedua belah pihak harus saling menunggu balasan selama beberapa waktu. Karenanya salah satu cara yang dapat mereka gunakan adalah dengan menggunakan pola tutur yang cukup lugas 
namun tidak terkesan agresif dan menekan. Hal ini pula yang dapat diindikasikan dari ketiadaan penggunaan kalimat direktif isyarat. Penggunaan isyarat akan semakin mengaburkan maksud pembeli maupun pedagang dan menghambat proses jual beli yang biasanya diharapkan terjadi dalam waktu yang sesingkat-singkatnya oleh kedua belah pihak. Selain itu, penggunaan kalimat performatif berpagar juga menjadi solusi agar maksud dapat disampaikan sejelas mungkin dalam kalimat-kalimat pendek tanpa memberi kesan agresif.

\section{KESIMPULAN}

Berdasarkan dati data yang telah dipaparkan sebelumnya, maka dapat disimpulkan bahwa cara penjual dan pembeli bertindak tutur direktif dalam percakapan di Forum Jual Beli Kaskus sebagian besar hampir mirip, namun terdapat sedikit perbedaan. Baik penjual maupun pembeli bertindak tutur direktif dengan cara menggunakan kalimat imperatif dan kalimat performatif berpagar. Akan tetapi, yang membedakan adalah dari tindak tutur direktif yang dilakukan oleh penjual terhadap pembeli mereka menggunakan kalimat keharusan. Penjual melakukan pernyataan keharusan kepada pembeli sebab ia memiliki wewenang lebih terhadap produknya tentang peraturan yang berlaku dalam kegiatan transaksi. Sedangkan tindak tutur direktif yang dilakukan oleh pembeli terhadap penjual yakni dengan menggunakan pertanyaan, bertujuan untuk menyuruh penjual agar berkenan melakukan keinginan dan kehendak mereka melalui tuturan yang tidak langsung sehingga suruhan mereka terdengar lebih halus.

Melalui penelitian ini, diharapkan tindak tutur direktif pada tuturan baik penjual maupun pembeli dapat digunakan sebagai contoh dalam kegiatan transaksi jual dan/ beli di masyarakat, khususnya pada situs pasar online lainnya. Sehingga maksud dan keinginan penutur terhadap mitra tuturnya dapat tercapai dengan baik dan sesuai dengan kondisi situasi tuturnya. Selain itu, penelitian ini diharapkan dapat menjadi masukan bagi peneliti selanjutnya yang meneliti tentang tindak tutur direktif dalam transaksi bisnis, khususnya di situs pasar online.

\section{DAFTAR PUSTAKA}

Creswell, John W. 1994. Research Design. Qualitative \& Quantitative Approaches. California: SAGE Publications.

Elmita, W., Ermanto, Ratna, E. 2013. "Tindak Tutur Direktif Guru Dalam Proses Belajar Mengajar Di TK Nusa Indah Banuaran Padang”. Jurnal Pendidikan Bahasa dan Sastra Indonesia, (Online), Vol. 1, No. 2, (http://ejournal. unp.ac.id/index.php/pbs/article/download/1301/1128, diunduh tanggal 9 
Etnolingual Vol 3 No 2

November, 2019, 131-141

Juli 2014).

Etikasari, D. 2012. "Tindak Turtur Direktif Dalam Wacana Kelas (Kajian

Mikroetnografi Terhadap Bahasa Guru)". Jurnal Artikel Jurusan Sastra Indonesia Program Studi pendidikan Bahasa, Sastra Indonesia, dan Daerah Fakultas Sastra Universitas Negeri Malang, (Online), (http://jurnalonline.um.ac.id/data/artikel/artikelB5E740EBE305E4F19C571891FD712087. pdf, diunduh tanggal 9 Juli 2014).

http://id.wikipedia.org/wiki/Kaskus. Diunduh tanggal 4 Juli 2014 pukul 15.20.

http://www.scribd.com/doc/48254615/SEJARAH-SINGKAT-PRAGMATIK. Diunduh tanggal 9 Juli 2014 pukul 19.00.

http://support.kaskus.co.id/about/sejarah kaskus.html. Diunduh tanggal 4 Juli 2014 pukul 15.20.

Rahardi, Kunjana. 2009. Sosiopragmatik. Kajian Imperatif dalam Wadah Konteks Sosiokultural dan Konteks Situasionalnya. Jakarta: Penerbit Erlangga.

Sudaryanto. 1993. Metode dan Aneka Teknik Analisis Bahasa. Pengantar Penelitian Wahana Kebudayaan secara Linguistis. Yogyakarta: Duta Wacana University Press.

Yule, George. 1996. Pragmatik. Cetakan Pertama. Yogyakarta: Pustaka Pelajar 